\title{
Småstegs søkeprosesser: hvordan "disjointed incrementalism" kan benyttes for å forstå informasjonssøkeatferd
}

\author{
Af Nils Pharo
}

\begin{abstract}
Artikkelen presenterer Braybrooke og Lindbloms teori om "disjointed incrementalism" som kjennetegn for beslutningsfatning og det påvises hvordan denne kan appliseres på informasjonssøkeatferd. I artikkelen presenteres også tesen om at det eksisterer to paradigmer innen informasjonssøk, det strukturerte paradigmet utøvet av bibliotekarer og informasjonsspesialister og webparadigmet utøvet av legmenn.
\end{abstract}

Nils Pharo, Førsteamanuensis, Dr. Soc. ved Høgskolen i Oslo,Nils.Pharo@jbi.hio.no

\section{Introduksjon}

Helt siden Robert S. Taylors banebrytende artikkel fra 1968 (Taylor, 1968) har man erkjent at informasjonssøkere ikke nødvendigvis velger optimale strategier for sine informasjonssøk. Taylor (1968, s. 181) refererer til en empirisk studie av brukeres valg av informasjonssøkestrategier (Rosenberg 1966) for å belegge påstanden at "'ease of access' to an information system is more significant than 'amount or quality of information' retrievable".

Studier av informasjonssøkeatferd har siden påvist en rekke faktorer som bidrar til at den perfekte tilstanden av informasjonsgjenfinning ikke er mulig, først og fremst fordi mengden av potensiell relevant informasjon er altfor stor (Blair \& Maron, 1985), men også fordi søkerne er påvirket av en rekke forskjellige faktorer under søkeprosessene (Fidel \& Soergel, 1983).

Problemstillingen som utforskes i denne artikkelen er hvordan en generell modell for beslutningsfatning kan appliseres på informasjonssøkeres beslutninger under søkeprosesser.

Artikkelen er bygget opp på følgende måte: først skildres kontrasten mellom eksisterende informasjonssøkeparadigmer. Deretter følger en presentasjon av David Braybrooke og Charles E. Lindbloms (1970) teori om beslutningsfatning, i tredje del beskrives hvordan teorien stemmer overens med in- 
formasjonssøkeatferd og til slutt følger diskusjon og konklusjon.

\section{To paradigmer innen informasjonssøk}

I utgangspunktet kan man betrakte et digitalt informasjonssøk som et møte mellom en person med et mer eller mindre velformulert informasjonsbehov og et informasjonssystem. Informasjonssystemet kan være en enkelt database der eneste interaksjonsmulighet er søk, men det kan også være World Wide Web med et utall ressurser og interaksjonsmåter. Systemene vil også være mer eller mindre rigide med hensyn til hvilke krav de stiller til brukerne for å produsere resultater. Tradisjonelle databaser, levert av systemer som Dialog, vil kreve korrekt syntaks for å kunne levere fra seg meningsfullt materiale mens browsingbaserte systemer tilrettelegger for brukerne å følge assosiative strategier gjennom lenkevalg. Det vil si at de i forskjellig grad vektlegger behovet for avanserte søkeferdigheter hos brukeren.

Utviklingen av mer fleksible informasjonssystemer, mer presist World Wide Web, har også dramatisk endret informasjonsøkedomenet - i den grad av man kan betegne det som et paradigmeskifte. Fra å være en arena forbeholdt fagspesialister og bibliotekarer har digital informasjonssøking, i og med framveksten av webben, blitt integrert i svært manges arbeids- og fritidsliv.

La oss kalle det gamle paradigmet, dominert av søkeeksperter, for det strukturerte paradigmet. Det nye, først og fremst dominert av legmenn, kaller vi webparadigmet.

\section{Det strukturerte paradigmet}

I det strukturerte paradigmet blir det forutsatt stor systemkunnskap, velformulerte søkestrategier og rasjonell atferd. Søkerne er trent opp til å kunne frambringe optimale resultater basert på grundige tolkninger av informasjonsbehov, for eksempel som fagreferenter på et instituttbibliotek, informasjonsforvalter i et oljeselskap eller som bibliotekar i referansesamlingen i et større folkebibliotek. Avhengig av type informasjonsbehov hos sluttbruker kan søkestrategiene være optimalisert mot henholdsvis presisjon (stor andel relevante dokumenter blant de frambrakte) eller fullstendighet/recall (stor andel av de relevante dokumentene i databasen blir frambrakt). Kostnadsfaktoren vil ofte spille en rolle siden det i stor grad er abonnementsbaserte databaser der det betales per mengde nedlastet materiale eller tid benyttet.

Den tradisjonelle modellen av søkeatferd slik den oppfattes innen det strukturerte paradigmet tar altså utgangspunkt $i$ at brukerne er eksperter $i$ informasjonssøk. Det finnes en rekke lærebøker innen informasjonssøk som beskriver optimalisering av søkestrategier, den følgende 10 stegs-strategien er hentet fra en lærebok fra 2003 (Ackermann \& Hartman, 2003):

1. "Identify the important concepts of your search.

2. Choose the keywords that describe these concepts.

3. Determine whether there are synonyms, related terms, or other variations of the keywords that should be included.

4. Determine which search features may apply, including truncation, proximity operators, Boolean operators, and so forth.

5. Choose a search engine.

6. Read the instructions on the search engine's home page. Look for sections entitled "Help," "Advanced search," "Frequently Asked Questions," and so forth.

7. Create a search expression using syntax that is appropriate for the search engine.

8. Evaluate the results. How many hits were returned? Were the results relevant to your query?

9. Modify your search if needed. Go back to Steps 2 through 4 and revise your query accordingly.

10. Try the same search in a different search engine, following Steps 5 through 9 above."

Selv med velstrukturerte søkestrategier og bruk av fagdatabaser er det ikke mulig å oppnå perfekt gjenfinningseffektivitet i form av resultatlister som både har høy presisjon og høy fullstendighet. Dette skyldes blant annet språkets innebygde tvetydighet (se f.eks. Blair \& Maron, 1985). Imidlertid er intensjonen innenfor det strukturerte paradigmet å få et så optimalt resultat som mulig ved at man utnytter gjenfinningssystemets fasiliteter på en rasjonell måte.

\section{Web-paradigmet}

Marcia Bates (1989) var den første til å beskrive en alternativ modell av bruker-system interaksjon som brøt med det strukturerte paradigmet. Hun beskrev gjenfinningsprosesser som sto i kontrast til den tradisjonelle modellen, slik den for eksempel er gjengitt 
i Robertson (1977) og videreført i nyere lærebøker i websøk som i eksempelet ovenfor.

Innenfor web-paradigmet er det en mye mer sammensatt søkergruppe. Den domineres i stor grad av sluttbrukerne selv, som ikke har ekspertkompetanse i informasjonssøk. Deres søk er karakterisert av enkle søkemotorsøk det vil si søk med få termer og liten bruk av avanserte strategier (Spink \& Jansen, 2004). I tillegg kommer, som nevnt, den mer eller mindre målrettede og assosiative interaksjonen ved hjelp av hypertekstlenkene.

I Bates' artikkel om bærplukkingsmodellen (Bates, 1989) peker hun på at det er flere former for søkeatferd den tradisjonelle modellen ikke tar hensyn til, deriblant bibliometriske metoder som for eksempel bruk av referanselistene $\mathrm{i}$ artikler og bruk av siteringsindekser for å spore opp litteratur som har referert spesifikke artikler. Videre påpeker hun at det er et generelt trekk at informasjonssøkerne bruker skummemetoder (browsing) i tillegg til direkte søk i databaser. Hennes beskrivelse av søkeprosessen var basert på metaforen bærplukking, der søkeren plukker et og et dokument eller annen informasjon ("bær") og justerer informasjonsbehovet, og spørsmålet, i takt med det de lærer av gjenfunne dokumenter før de fortsetter til neste informasjonskilde.

I det følgende skal vi se på en teori som kan være med på å ytterligere forklare hvorfor søkere innen web-paradigmet ikke optimaliserer på samme måte som innen det strukturerte paradigmet, tvertimot skal vi se at det for sluttbrukere er rasjonelt å utforme søkestrategier som ikke er optimaliserte, men preget av å være iterative og ufullstendige. Braybrookes og Lindbloms teori om "disjointed incrementalism" er en av mange beslektede teorier som har bidratt til å øke vår forståelse av mennesker som beslutningstakere $i$ en kompleks verden.

\section{Braybrooke og Lindbloms teori om at endringer skjer i små steg}

Forfatterne bak denne teorien har bakgrunn fra flere fag, David Braybrooke fra filosofi og Charles E. Lindblom fra økonomi. Imidlertid er det innen rammene av statsvitenskap de arbeidet sammen om "disjointed incrementalism".
Braybrooke og Lindbloms teori om forandringer gjennom små steg er hentet fra boka "A strategy of decision" (1970), men den er kanskje mest kjent gjennom Lindbloms artikkel om "The science of 'muddling through"' (Lindblom, 1959). Teorien ble lansert som et alternativ til den rasjonalistiske eller synoptiske økonomiske teorien som hadde utgangspunkt $\mathrm{i}$ at aktørene har perfekt informasjon og er $\mathrm{i}$ stand til å vurdere alle konsekvenser av sine handlinger. I boka bruker de mange eksempler som kjennetegner endringer av byråkratiske systemer.

Kjernen i Braybrooke og Lindbloms teori er at et samfunnsområde utvikler seg gjennom små, inkrementelle steg i form av beslutninger som langsomt og "usynlig" medfører endringer. Svært sjelden vil det skje revolusjonære endringer. På denne måten vil samfunnet sakte men sikkert utvikle seg, men uten at dette i opprørende grad påvirker samfunnsdeltagerne. Disse endringene er kjennetegnet av en del identifiserbare egenskaper, deriblant at:

- Et begrenset antall alternativer og konsekvenser av handlingene blir vurdert av de som initierer endringene. Det er godt mulig at man er klar over andre alternativer, men dersom disse vil medføre store endringer blir de lagt til side og ikke tatt hensyn til.

- Målene tilpasses middelet, det vil si at organisasjonen justerer på de målsetningene man kan oppnå relatert til de virkemidlene man har for hånden. Dersom et ideelt mål vurderes som uoppnåelig i en gitt situasjon blir målet reformulert.

- Dataene bidrar til rekonstruksjon i forhold til problemstillingen. Det betyr at samtidig som målene tilpasses vil også dataene som ligger til grunn for målene omtolkes for best mulig å støtte opp om måloppnåelsen.

- Problemer analyseres og evalueres over lang tid. Mange "problemer" er uløselige, men utgjør heller områder som gjennomgår inkrementelle endringer over tid som resultat av stadige analyser og evalueringer.

Som vi ser beskriver teorien en svært pragmatisk tilnærming til problemløsning. I det følgende skal vi se nærmere på hvordan disse egenskapene også gir seg til kjenne under informasjonssøkeprosesser, og særlig websøk. Det vil si at vi betrakter denne typen prosesser som serier av beslutninger som søkeren tar i løpet av prosessen. 
Begrensning $i$ antall alternativer søkeren tar hensyn til

På grunn av mengden mulige informasjonskilder tilgjengelig på webben, begrensninger i søkerens fantasi og i hans/hennes kognitive kapasitet vil søkeren kun være i stand til å oppsøke et begrenset antall av de potensielt relevante kildene som er tilgjengelig. Søkeren vil være mer eller mindre bevisst om at det eksisterer andre webtjenester som kunne ha hjulpet til med å løse oppgaven, verifisere kunnskapen eller avfeie hypotesen han/hun arbeider med. Videre utfører de fleste websøkere i stor grad enkle søk, typisk lengde er 2-3 ord per søk (Spink \& Jansen, 2004), noe som gir dem svært store treffmengder. Det er imidlertid sjelden søkere ser på mer en de to første sidene i trefflisten, de fleste ser bare på den første. Vi må anta at dette gir dem tilstrekkelig med relevante dokumenter til at de kan arbeide videre med oppgaven sin. Videre vil det at man er bevisst om det begrensede grunnlaget man har for å ta avgjørelsen $\mathrm{i}$ større eller mindre grad understøtte ens egen tillit til at avgjørelsen er riktig.

I de færreste tilfeller er nok dette noe som ødelegger nattesøvnen til informasjonssøkerne. I tilfeller der søkeren vet hva han/hun er på jakt etter ("known item"-søk) vil det være tilstrekkelig å finne svaret ett sted. Eksempler på det er søk etter fakta som fotballresultater ("Hva ble resultatene i forrige runde i eliteserien?") eller geografiske opplysninger ("Hva er hovedstaden i Georgia?"). Mer komplekse informasjonsbehov kan føre til at søkeren interagerer med flere kilder, for eksempel for å identifisere miljøvennlige energikilder for hjemmet. Imidlertid vil også slike søk ofte bære preg av at søkeren har behov for å finne tilstrekkelig med informasjon til å ta en avgjørelse, framfor å finne alle fordeler og ulemper ved samtlige alternativer. Ofte vil søkeren foretrekke å benytte seg av kilder han/hun kjenner fra tidligere og unngå ukjente nettressurser (Pharo, 2002).

\section{Målene tilpasses midlene}

I undersøkelse av reelle websøk har Pharo (2002) observert mange tilfeller av at søkerne justerer på sine opprinnelige informasjonsbehov som resultat av erfaringer de gjør i løpet av søkesesjonen. Det kan være at ressursene som søkeren finner ikke helt er i stand til å tilfredsstille behovet og at de derfor velger å endre på målsettingen framfor å forsøke å finne mer optimale svar. Et eksempel på denne typen justering er søkerne som leter etter spesifikke ikoner til bruk i utviklingen av et nettsted (Pharo \& Järvelin, 2006, s. 229). Ved første gangs gjennomsyn av en rekke kandidater vurderer de ingen som relevante for sine behov. En stund senere, etter å ha vurdert en del andre løsninger, har de imidlertid bestemt seg for at de likevel kan benytte et av ikonene. Dette kan fortolkes til at de har foretatt en justering av sitt opprinnelige mål slik at ikonet de fant likevel kan benyttes.

La oss benytte et mer dagligdags eksempel: du har planlagt å finne oppskriften til dagens middag på matnettstedet aperitif.no, da du har hatt svært god erfaring med dette tidligere. Det viser seg imidlertid at de ikke har oppskriften på retten du planlegger, derimot viser det seg at de har oppskrift på en rett med en del av de samme ingrediensene. Resultatet blir at du endrer mål og måltid for den dagen.

Det er selvsagt mulig å fortolke disse eksemplene annerledes, for eksempel kan man hevde at søkeren hadde et uklart informasjonsbehov som han/hun forsøkte å uttrykke på en måte som ikke møtte eksakt respons fra systemet. Dette skal vi studere i nærmere detalj nedenfor. Vi ser også at fenomenet serendipitet, funn ved slump, er beslektet med denne typen informasjonssøkeatferd. Imidlertid bør serendipitet, etter min mening, reserveres til bruk for å beskrive mer vilkårlige oppfyllelse av informasjonsbehov enn tilfellet er i disse eksemplene.

\section{Rekonstruksjon basert på funnet informasjon}

Beslektet med foregående punkt er situasjoner der søkeren som resultat av de ressursene han/hun finner bestemmer seg for å reformulere sin problemstilling. Forskjellen er at i det foregående eksempelet bestemmer søkeren seg for å tilpasse problemstillingen til de data som han/hun finner mens i dette tilfellet har søkeren en uklar forståelse av sitt opprinnelige informasjonsbehov. Det vil si at vedkommende har det Belkin kaller en "anomal kunnskapstilstand", en såkalt ASK (Belkin, Oddy \& Brooks, 1982).

Når søkeren så velger å gå ut med en bred, browsingbasert søkestrategi skyldes det et behov for å bygge opp tilstrekkelig med kunnskap basert på det uklare initielle behovet. Dette kan søkeren gjøre ved å oppsøke nettsider som ser ut til å omhandle problemer som på et eller annet vis henger sammen med hans/ hennes problemforståelse. På denne måten kan man betrakte det som at søkeren går i dialog med andre li- 
kesinnede og derigjennom konstruerer kunnskap som komplementerer hans/hennes eksisterende forståelse.

En søker som i utgangspunktet ønsker å finne "noe om Karlheinz Stockhausen" ender kanskje opp med dyp interesse for komponisten Arnold Schoenberg og hvordan tolvtoneskalaen som han utviklet har påvirket moderne musikk. Det betyr ikke at søkeren nødvendigvis endret informasjonsbehov fordi han ikke fant noe om Stockhausen. Endringen kan skyldes at "Stockhausen" utgjorde søkerens eneste holdepunkt for "avansert musikk som brøt med eksisterende paradigmer innenfor klassisk musikk", og at han/hun forstod gjennom sin interaksjon med forskjellige kilder at Schoenberg var et mer relevant utgangspunkt for problemstillingen. Med andre ord oppnådde søkeren en læringseffekt gjennom interaksjonen med systemet.

En slik gradvis innsnevring og endring av problemstillingen innenfor et bredt "temaområde" er også et karakteristikum ved den typen beslutningsfatninger som Braybrooke og Lindblom undersøkte. De beskriver saksbehandlere som transformerer problemene i takt med datainnsamlingen med tilhørende inkrementell endring av kriteriene som benyttes i saksbehandlingen.

Denne typen informasjonssøkeatferd har vært belyst med forskjellige teoretiske perspektiver tidligere. Et eksempel er Dervins konstruktivistiske "sense-making" metodologi (Dervin, 1992). Den er utviklet med tanke på å "fravriste" informasjonssøkerne deres egentlige informasjonsbehov ved hjelp av særskilt utviklede intervjuteknikker.

\section{Problemer analyseres og evalueres over lang tid} Problemløsning skjer ofte i form av lengre prosesser som skjer i nært samspill med ens omgivelser. Noen problemer er svært komplekse og vil ikke bli løst på lang tid. I et samfunnsperspektiv vil dette kunne være behovet for å sikre arbeid til alle landets borgere, en problemstilling hvis "løsning" vil variere, blant annet med skiftende politiske regimer. Det at et problem vil forandre seg over tid betyr også at informasjonsbehovene og potensielle informasjonskilder blir vurdert forskjellig på ulike tidspunkt.

I tilknytning til en større arbeidsoppgave vil ofte søkeren ha behov for å benytte samme datamateriale på forskjellige tidspunkt. Selv om informasjonsbehovet er uttrykt relativt likt på ulike stadier i arbeidsprosessen vil vurderingen av samme informasjonskilde kunne endre seg fra gang til gang. Innen akademia kan man tenke seg at arbeidet med et doktorgradsprosjekt parallelt følges av en longitudinell studie for å undersøke doktorandens informasjonssøkeatferd i løpet av prosjektet. Da vil man antakelig finne at samme websøk utført på en rekke forskjellige tidspunkt i prosessen resulterer i forskjellige vurderinger av kildenes relevans og brukbarhet for essensielt forskjellige formål.

Carol Kuhlthaus (2004) modell av informasjonssøkeprosesser beskriver hvordan informasjonssøkerne i tidlige stadier av problemløsningen opptrer usikkert og famlende, nettopp fordi de ennå ikke har funnet et fokus. Med en inkrementell endring av problemstillingen vil informasjonskilder som på et stadium syntes relevante svinne ut av forskerens forståelseshorisont mens andre ressurser som tidligere ble bedømt til å være "for tekniske" eller "for abstrakte" anses som tilfredstillende.

\section{Diskusjon}

I de foregående eksemplene har det blitt forsøkt å illustrere hvordan de valgene informasjonssøkere foretar under søkeprosesser knytter an til en generell teori om beslutningstaking. Teorien som er benyttet kan betraktes som en videreføring av Simons begrensede ("bounded") rasjonalitet og er nært beslektet med lignende teorier som for eksempel Cohen, March og Olsens (1972) garbage can-teori.

Herbert Simon er regnet blant de viktigste samfunnsforskerne i forrige århundre. Han var utdannet som statsviter, men var svært tverrvitenskapelig interessert og er blant annet kjent for sitt arbeid med kunstig intelligens og ikke minst som Nobelprisvinner i økonomi.

Simons teori om begrenset rasjonalitet og satisficing er allerede godt beskrevet i hans doktoravhandling "Administrative behavior" (Simon, 1976 - førsteutgaven kom ut i 1947) der særlig kapitlene som tar for seg hvordan sosiale sammenhenger i organisasjoner og psykologiske effekter hos enkeltpersoner påvirker deres avgjørelser. Hovedpoenget for Simon er at bildet av mennesket som rasjonell aktør - the economic man - ikke er et fruktbart utgangspunkt for å studere og analysere problemløsning. Den rasjonelle model- 
len er basert på at man har full oversikt over samtlige alternative handlinger og konsekvenser av dem. Det vil være konsekvenser langs en rekke dimensjoner og Simon (1976, s. 81-84) påpeker at

1. mennesket ikke vil være i stand til å ha komplett kunnskap om alle konsekvensene av ens valg. Kunnskap om konsekvenser vil alltid være fragmentarisk

2. siden konsekvensene ligger i framtida vil vurderingen av dem være uklare fordi man ikke kan eksakt bedømme dem før de faktisk har skjedd

3. det eksisterer en rekke mulige handlingsalternativer og konsekvenser som mennesket ikke vil være i stand til å forestille seg på grunn av ens manglende persepsjons- eller forestillingsevne.

Simon introduserer derfor begrepet begrenset rasjonalitet for å beskrive de forutsetningene som avgjørelser fattes innenfor. En person vil ikke bare forenkle verden, men også la seg styre av sosiale roller han inngår i, for eksempel hva som er forventet/stadfestet informasjonspolitikk i en yrkesgruppe eller et firma. Videre vil følelsesmessige faktorer spille inn, for eksempel kan personen være preget av en personlig krise som gjør at oppmerksomheten ikke er helt på topp.

Videre introduserer han termen "satisfice", som en kombinasjon av de engelske verbene "satisfy" og "suffice", denne benytter han for å betegne det å ta avgjørelser som er tilstrekkelig gode for å løse en oppgave eller problem. Tendensen til å løse oppgaver ved hjelp av prøving og feiling, såkalt heuristikk, er et eksempel på en oppførsel som er av satisficeart. En person vil konstruere en "stoppregel" (Simon, 1979 sitert av Agosto, 2002) som forteller ham når en alternativ løsning tilfredsstiller tilstrekkelig mange behov til at den er akseptabel. Simon bruker selv et eksempel på salg av hus, en versjon av dette kan være selgeren som er fornøyd og velger å selge huset sitt når han oppnår en god nok kombinasjon av pris, finansieringsplan og overtagelsesdato. Han kan ikke vite sikkert om ytterligere utsettelse av salget kunne gitt ett enda mer optimalt resultat.

Innen vårt domene har blant annet Denise Agosto (2002) utført en interessant studie der formålet var å undersøke hvorvidt begrenset rasjonalitet og satisficing påvirket unge kvinners websøkeatferd. Blant annet identifiserte hun den enkle stoppregelen for å avbryte et søk: "when you get bored".

Selv om ideene om satisficing og inkrementelle endringer er utviklet for å beskrive mer komplekse sammenhenger er det forhåpentlig blitt forståelig gjennom denne teksten at de også kan benyttes som gyldige forklaringer for å forstå søkeatferd.

Som påvist har tidligere forskning resultert i teorier som hver for seg overlapper det vi her har betraktet som egenskaper ved en helhetlig teori om inkrementelle endringer. Dervin, Belkin og Kuhlthau har alle bidratt til å berike våre kunnskaper om menneskers prosessering av informasjonsbehov. Ved å applisere Braybrooke og Lindbloms generelle teori for beslutningsfatning på området informasjonssøk ser vi at den kan benyttes til å beskrive ASK-situasjoner (Belkin, Oddy \& Brooks, 1982) så vel som kunnskapskonstruksjon (Dervin, 1992) og stadier i informasjonssøkeprosesser (Kuhlthau, 2004).

Innen forskning på informasjonssøkeatferd har det videre vært mye fokus på arbeids- og søkeoppgaver (tasks) de siste årene. Det er utvilsomt en sammenheng mellom for eksempel oppgavens kompleksitet (Byström \& Järvelin, 1995) og i hvilken grad søkerne er i stand til å formulere informasjonsbehov.

Bates modell av informasjonssøkeprosesser ble utviklet med tanke på utforming av bedre grensesnitt for informasjonssystemer. Den trekker i stor grad veksler på observasjon av informasjonssøk i manuelle systemer. Det er derfor interessant å se hvor godt hun traff i sin beskrivelse av søkeren som begynner med et svært bredt eller løst definert informasjonsbehov som gradvis endres ettersom søkeren ledes fra kilde til kilde. Denne prosessen utgjør en parallell til websøkeprosesser slik de er beskrevet over og har stor overføringsverdi for å forstå websøk.

På den annen side er også bærplukkingsmodellen utviklet innenfor det strukturerte paradigmet, Bates beskriver søkere som arbeider med tanke på å oppnå høy gjenfinningseffektivitet - "complete recall". Hun differensierer også mellom søking, der hun inkluderer browsing, og "casual, don't-know-what-I-want behavior" - det vil si at hun trekker et skille mellom rasjonelt strukturert søking og den mer assosiasjonspregede interaksjonen som kjennetegner mange websøkere. Dette skillet er jo også utgangspunktet for de 
to paradigmene som vi har satt opp mot hverandre. Som hevdet ovenfor er ikke nødvendigvis optimal fullstendighet eller presisjon relevante rettesnorer for søkerne, å få gode nok svar kan ofte være tilstrekkelig.

Websøkere opererer innenfor rammer som det er umulig å få full oversikt over, med milliarder av nettsider og uendelige mengder av lenker. De direkte kostnadene ved å bruke web er imidlertid små, utover tiden som bli investert. Det betyr at søkerne kan tillate seg å prøve og feile, være pragmatiske i sine strategier og justere målsetningene.

Det kan innvendes at resultatene av heuristiske, satisfice-drevne og ikke-rasjonelle søkestrategier ikke frambringer like relevante dokumenter som optimaliserte søk. Enkelte hevder at manglende informasjonskompetanse blant legmenn legitimerer bibliotekarenes og bibliotekenes fortsatte eksistens og påpeker at alternativet vil være en tilnærmet katastrofe for kunnskapssamfunnet.

Ved å se på informasjonssøk som beslutningstakingsprosesser kjennetegnet av inkrementelle endringer skifter vi imidlertid perspektiv på søkeprosessen. Fra å se på søkeren som herskeren over kunnskapsuniverset (en utopi) går vi over til å betrakte ham/ henne som en utøver av rasjonelle valg $i$ en prosess der målet er å bli tilstrekkelig fornøyd. Søkeatferd som ser irrasjonell ut fra det strukturerte paradigmets synsvinkel oppfattes av den som utfører den som svcert rasjonell - søkeren prioriterer innenfor en kontekst preget av tidspress, akkumulerte kunnskaper om hvilke kilder som er brukbare, forventninger fra de sosiale omgivelsene samt en rekke andre faktorer som påvirker søkestrategiene.

Det eksisterer to paradigmer innen informasjonss $ø$, og behovet for eksperter som behersker det strukturerte paradigmet er betydelig. Paradigmene er dels karakterisert av forskjellige holdninger dels i forhold til teknikk og teknologi. Holdningsmessig kjennetegnes paradigmene ved at optimal gjenfinningseffektivitet står sentralt i det strukturerte paradigmet mens webparadigmet sikter mot "tilfredsstillende svar". Erfaringene og teknikkene fra strukturert informasjonssøk vil sildre over i websøk, det er mye eksperimentering med å la programvare ta over avanserte søk, som i visjonen om den semantiske webben og vi vil antakelig oppleve en stadig, om enn inkrementell, forbedring av websøkemotorene gjenfinningseffektivitet. Antakelig vil de holdningsmessige karakteristikaene være det som i størst grad bidrar til å opprettholde paradigmene.

Til slutt må det påpekes at teorien om inkrementelle endringer har møtt mye kritikk innen sitt opprinnelige domene, statsvitenskapen. En oppsummering finnes for eksempel i Woodhouse og Collingridge (1993). Kjernen i mye av kritikken er at den i liten grad har gjort aktørene i stand til å bli bedre inkrementalister, med andre ord har man etterlyst strategier som gjør oss i stand til å foreta mer informerte valg i løpet av prosessen. I lys av dette foreslås her noen tiltak som kan støtte opp under legmenns webinformasjonssøkeprosesser. Forslagene er utformet med tanke på å gjøre informasjonen som tilbys sluttbrukerne mer ensartet eller strømlinjeformet slik at det skal bli lettere for brukerne å justere på søkestrategiene under prosessen. To hovedområder peker seg ut som spesielt relevante:

1. Mer støtte i form av anbefalinger under browsing, for eksempel ved å markere lenker til ofte benyttede sider eller funksjoner

2. Mer avanserte trefflister fra søkemotorene, for eksempel ved bruk av clustering i søkemotorer, basert på enkeltsidenes bruk så vel som emnemessig likhet

I tillegg bør det utvikles læremateriell for informasjonssøk som tar utgangspunkt i søkernes forutsetninger. Det vil si å legge mindre vekt på å lære bort teknikker for å sette opp strukturerte søkestrategier på bekostning av mer bruk av eksempler

Informasjonseksplosjonen er ikke ny med weben, det som er nytt er at kunnskapsorganiseringen og informasjonssøkingen i mye større grad enn tidligere overlates til legmenn.

\section{Referanser}

Ackermann, E \& Hartman, K (2003). Searching and researching on the Internet and the World Wide Web. 3rd ed. Wilsonville, Or: Franklin Beedle \& Assoc.

Agosto, DE (2002). Bounded rationality and satisficing in young people's Web-based decision making. 
Journal of the American Society for Information Science \& Technology, 53, 16-27.

Bates, M (1989). The design of browsing and berrypicking techniques for the on-line search interface. Online Review, 13(5), 407-424.

Belkin, N, Oddy, R \& Brooks, H (1982). ASK for information retrieval: Part I. Background and theory. Journal of Documentation, 38(2), 61-71.

Blair, DC \& Maron, ME (1985). An Evaluation of Retrieval Effectiveness for a Full-Text DocumentRetrieval System. Communications of the ACM, 28(3), 289-299.

Braybrooke, D \& Lindblom, CE (1970). A strategy of decision: policy evaluation as a social process. New York: Free Press.

Byström, K \& Järvelin, K (1995). Task complexity affects information seeking and use. Information Processing and Management, 31(2), 191-213.

Cohen, MD, March, JG \& Olsen, JP (1972). A garbage can model of organizational choice. Administrative Science Quarterly, 17(1), 1-25.

Dervin, B (1992). "From the mind's eye of the user: the sense-making qualitative-quantitative methodology". I Glazier, JD, Powell, RR (Eds), Qualitative research in Information Management, Libraries Unlimited, Englewood, CO, pp.61-84

Fidel, R \& Soergel, D (1983). Factors affecting online bibliographic retrieval: A conceptual framework for research. Journal of the American Society for Information Science, 34(3), 163-180.

Lindblom, CE (1959). The science of "muddling through". Public Administration Review, 19(2), 7988 .
Kuhlthau, CC (2004). Seeking meaning: a process approach to library and information services, 2. Utg.. Westport, Conn.: Libraries Unlimited.

Pharo, N (2002). The SST method schema: a tool for analysing Web information search processes. Tampere: University of Tampere

Pharo, N \& Järvelin, K (2006). 'Irrational' searchers and IR-rational researchers. Journal of the American Society for Information Science and Technology, 57(2), 222-232.

Rosenberg, V (1966). The application of psychometric techniques to determine the attitudes of individuals tow3ard information seeking. Bethlehem, PA: Lehigh University.

Robertson, SE (1977). Theories and models in information retrieval. Journal of Documentation, 33 (2), 126-148.

Simon, HA (1976). Administrative behavior. New York: Free Press.

Simon, HA (1979). Models of thought. New Haven, CT: Yale University Press.

Spink, A \& Jansen, BJ (2004). Web Search: Public Searching of the Web. Dordrecht: Springer.

Taylor, RS (1968). Question negotiation and information seeking in libraries. College and Research Libraries, 29, 178-194.

Woodhouse, EJ \& Collingridge, D (1993). "Incrementalism, Intelligent Trial-and-Error, and the Future of Political Decision Theory, Edward J. Woodhouse and David Collingridge". I Redner, H. (Ed.), An Heretical heir of the enlightenment : politics, policy, and science in the work of Charles $E$. Lindblom, Boulder, Westview, CO, pp. 131-154 